\title{
FLUID INCLUSION STUDY OF THE MORRO AGUDO PB-ZN DEPOSIT, MINAS GERAIS, BRAZIL
}

\section{IONÁ DE ABREU CUNHA ${ }^{1}$, CARLOS EDUARDO SILVA COELHO ${ }^{1,2}$ AND AROLDO MISI ${ }^{1}$}

\begin{abstract}
The Morro Agudo is the only $\mathrm{Zn}-\mathrm{Pb}$ mine in Brazil, with an ore reserve of 9,470,000 tonnes, at average grades of 6.13\% $\mathrm{Zn}$ and $2.00 \% \mathrm{~Pb}$. The host rocks are dolomites from the Morro do Calcário facies of the Vazante Formation, Bambuí Group. The ore is composed of sphalerite and galena. Gangue minerals include dolomite, quartz, barite and calcite. The Morro Agudo mineralization is closely associated with a N-S trending fault zone, which dips from 20 to 70 degrees towards the west. The orebodies are stratabound and sometimes displaced by late faults. Shallow-water sedimentary structures such as teepee, laminated stromatolites and microcrystalline quartz nodules (length-slow type) suggest an evaporitic paleoenvironment. The structural and textural nature of the mineralization, as well as some replacement features of the ore, indicate that the main mineralization stage occurred in the early stages of diagenesis. Fluid inclusion (FI) studies of primary and pseudosecondary FI in sphalerite crystals indicated moderate saline solutions (around $14 \% \mathrm{wt} \mathrm{Eq.} \mathrm{NaCl}$ ). The wide distribution of salinity values within the orebodies could be related to the higher salt concentration in the fluid near the fault zone. Total homogenization temperature and salinity data indicate a zoning pattern closely related to the main fault zone. Paleotemperatures are relatively higher in the 'A' Block, closer to the main fault zone. Away from the fault, temperatures reduced gradually. The stratiform ore of the 'N' Body exhibits the lowest temperature interval.
\end{abstract}

Keywords: $\mathrm{Pb}-\mathrm{Zn}$ deposit, fault zones, fluid inclusion, sphalerite.

INTRODUCTION The study area is at Morro Agudo, Paracatu, in the NW part of the State of Minas Gerais.

The lead-zinc mineralizations of Morro Agudo (MA) occur within carbonate sequences of the Vazante Formation (Dardenne 1978a, 1979) or Vazante Group (Dardenne et al. 1998), exposed at the western flank of the Morro do Calcário (Limestone Hill), which has been interpreted alternatively as a stromatolitic bioherm or as a reef barrier structure (Dardenne 1978b, Madalosso and Valle 1978, Madalosso 1980a).

The mineralization of Morro Agudo is part of a N-S regional trend of lead-zinc occurrences, with an approximate length of $300 \mathrm{~km}$, which includes the well-known Vazante Mine. The Morro Agudo deposit is limited by a normal fault striking N10-20E, with an average dip of $20^{\circ}$ towards west.

HOST ROCKS The Morro Agudo deposit is hosted by a sequence of dolarenites and intraformational breccias belonging to the Morro do Calcário facies of the Vazante Formation. These units are thought to partially represent the post-reef subfacies (Madalosso and Valle 1978). The ore is limited to the west by a well-defined interfingering contact between host rocks and the lithologies of the Morro Agudo facies of the Vazante Formation.. The mineralization is intercepted to the east side by a normal fault system, which trends roughly N-S (Fig. 1). The mine has been subdivided into three blocks ('A', 'B' and 'C') in relation to the main fault zone (Fig.1).

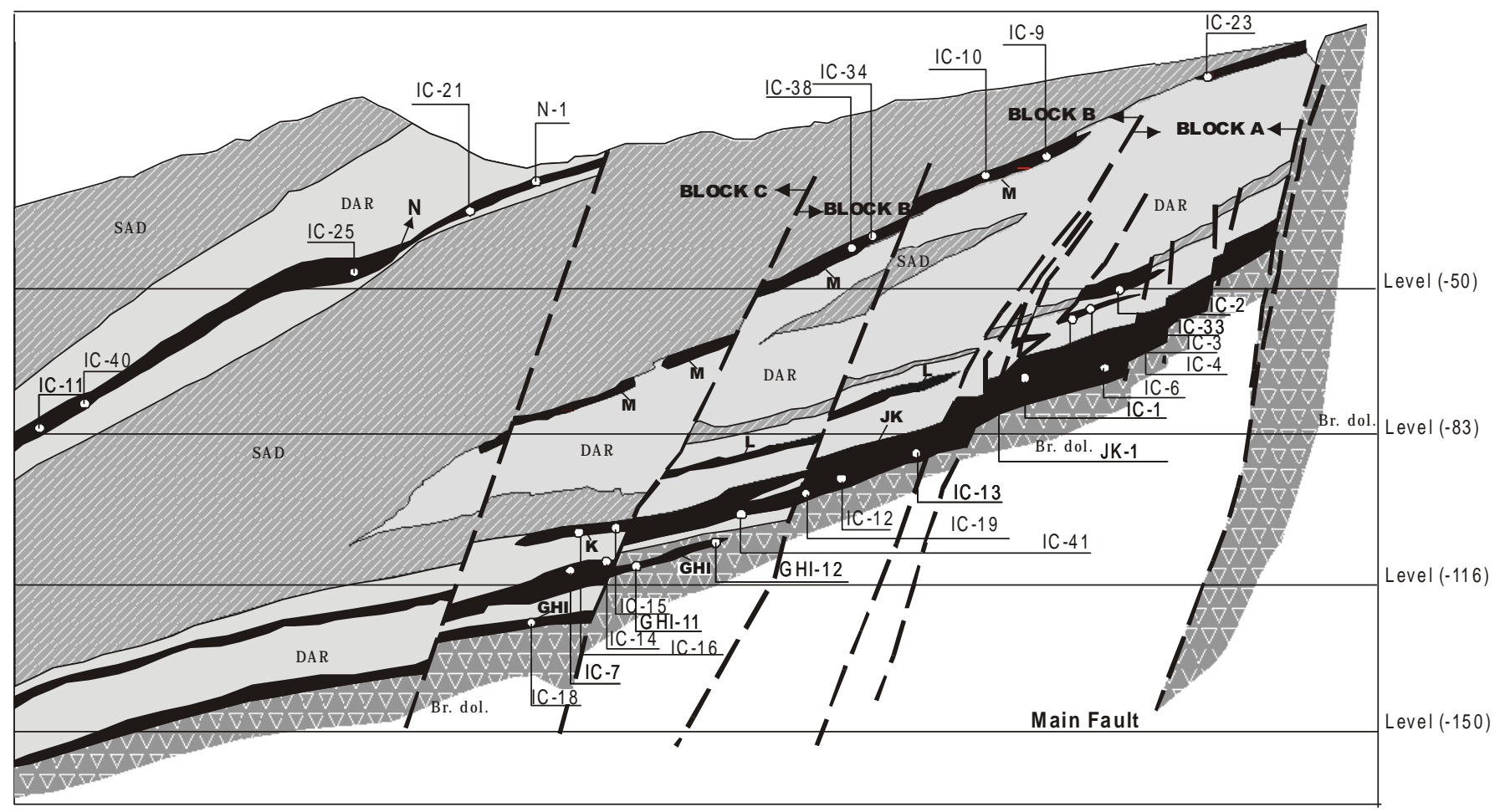

LEGEND

Ore

SAD - Shale-dolomitic sequence

DAR - Dolarenite + Dolarenitic Breccias

Br. dol. - Dolomitic Breccias

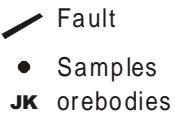

Figure 1-Location of the sampled stations along the east-west section, line 74 of the underground mine of Morro Agudo. Source: CMM Internal Report.

1 Research Group on Metallogenesis, Centro de Pesquisa em Geofísica e Geologia and Curso de Pós-Graduação em Geologia, Instituto de Geociências, Universidade Federal da Bahia. Rua Caetano Moura, 123 40210-340 - Federação, Salvador-Bahia, Brazil E-mail: iona@cpgg.ufba.br, misi@ufba.br

2 Conselho Nacional de Desenvolvimento Científico e Tecnológico - CNPq (ccoelho@cpgg.ufba.br) 
Four main lithotypes have been identified in the mine: dolomitic breccias (dolorudites), dolarenitic breccias, dolarenites and a shaledolomitic sequence (Romagna and Costa 1988). Fig. 1 shows the location of the sections and of the sampling sites in the underground workings.

Dolomitic Breccias are intraformational breccias, occurring at the base of the stratigraphic column of the mine, composed of angular clasts of varied sizes, enclosed in a dolomitic matrix. Dolarenitic breccias are made of fragments of laminated to massive dolomites and dolarenites as in the basal lithotype. The matrix of these rocks is composed of dolarenitic, poorly sorted, medium grained dolomite grains. Dolarenites are light- to mid-grey, composed by coarse- to medium-grained alochems. Partial or complete substitution of alochems by sphalerite is a characteristic feature in these rocks. The dolomitic shale sequence is formed by millimeter to centimeter-thick laminae, dominated either by dolomitic or carbonaceous shale.

Mineralization The ore deposits at Morro Agudo exhibit both structural and stratigraphic controls. The ore mineralogy is relatively simple, dominated by sphalerite and galena. Pyrite is subordinate in all orebodies of the mine. Gangue minerals include barite, dolomite, calcite and quartz.

Eight orebodies have been individualized ('G', 'H', 'I', 'J', 'K', ' $\mathrm{L}$ ', ' $\mathrm{M}$ ' and ' $\mathrm{N}$ ' orebodies), which are generally grouped into the 'GHI', 'JKL', 'M' and 'N' bodies (Romagna and Costa 1988). The CMM mine staff has divided the mine into three blocks (' $A$ ', 'B' and ' $\mathrm{C}$ '), according to their relative position with respect to the main fault zone (Fig. 1). Four types of mineralization have been defined: stratiform, oolitic, brecciated and venular. These types are described below.

Stratiform mineralization is represented by the ' $\mathrm{N}$ ' orebody, which is placed at the upper part of the dolarenite unit, intercalated with the dolomitic shale sequence (Fig. 1). Mineralization occurs as fine rhythmic and parallel horizons of very fine grain size and disposed according to the original bedding surfaces of the carbonates.

The oolitic ore is formed by sphalerite, galena and pyrite in fine to medium grain sizes, occurring as cements and filling porous spaces in the dolarenites. This ore type is generally massive and represented by the ' $J$ ', ' $K$ ', 'L' and ' $M$ ' bodies.

The 'GHI' (dolomitic breccias) and the 'JKL' (dolarenitic breccias) orebodies represent mainly brecciated mineralization. They occur mainly in the rock matrix, and occasionally in clasts with sacaroidal texture. The replacement character of the sphalerite is typical in this ore type.

Venular mineralization occurs as fracture in fillings that crosscut the mineralizations above described. It is observed in orebodies ' $G$ ', 'H', 'I', 'J', 'K', 'L' and 'M' and rarely in the 'N' orebody. Sphalerite and galena appear in late fractures, in ooids and intraclasts of dolarenites.

FLUID INCLUSION SYSTEMATICS Microthermometric measurements were performed on a Chaixmeca heating-freezing stage attached to a Nikon microscope equipped with a x100 Nikon objective of the Metallogenesis Laboratory at Federal University of Bahia. Laser Raman microspectroscopic analyses (LRM) were performed at the Fluid Inclusion Laboratory of the Geoscience Institute, University of Campinas, using a Jobin Yvon model T64000.

The study was restricted to primary and pseudosecondary (cogenetic) inclusions in sphalerites. These inclusions generally present reduced dimensions in all orebodies, with larger diameters varying from 5 to $25 \mathrm{~mm}$ and with varied shapes (negative crystal, octahedral, sharp tubular and irregular).

With respect to the fluid content at room temperature, two types of inclusions have been identified such as: (i) two-phase $(\mathrm{L}+\mathrm{V})$, with degree of fill (DF) varying from 0.8 to 0.95 and (ii) monophase inclusions. The two-phase inclusions showed, during the cooling run, freezing temperature of about $-60^{\circ} \mathrm{C}$, indicating aqueous nature. The monophase inclusions showed the development of a vapor bubble followed by freezing around -60 to $-70^{\circ} \mathrm{C}$. Some monophase inclusions that did not exhibit any phase change during the cooling run were analyzed by Raman microspectroscopy and no identifiable gas phases have been detected. These inclusions could be filled by a mixture of other volatile phases different from $\mathrm{H}_{2} \mathrm{O}\left(\mathrm{CH}_{4}, \mathrm{~N}_{2}\right)$ or simply be empty cavities due to leakage. Inclusions are isolated and disseminated inside the sphalerite crystals or forming intragranular (pseudosecondary) and transgranular (secondary) fluid inclusion planes.

Microthermometric Data The histograms were individualized according to the different orebodies, with the aim of searching for a possible lateral and/or vertical thermal zoning.

During heating from very low temperatures, melting temperatures in the inclusions from the ' $\mathrm{JKL}$ ' orebodies in the 'A' block showed a scattered distribution of values from $0^{\circ} \mathrm{C}$ to $-36^{\circ} \mathrm{C}$, with well-defined maxima at $-10^{\circ} \mathrm{C}$ (Fig. 2c). The results obtained for the ' $\mathrm{C}$ ' block clearly denote the decrease of this interval, varying from $-4^{\circ} \mathrm{C}$ to $12^{\circ} \mathrm{C}$, with well-defined maxima close to $-10^{\circ} \mathrm{C}$ (Fig. 2a). The few data obtained for inclusions of samples of the ' $\mathrm{B}$ ' block are included in the range of the ' $A$ ' and ' $C$ ' blocks (Fig. 2b).

The melting temperatures obtained for fluid inclusions in sphalerite from the ' $\mathrm{M}$ ' body vary between $0^{\circ} \mathrm{C}$ and $-12^{\circ} \mathrm{C}$, with well-defined maxima at $-7^{\circ} \mathrm{C}$ (Fig. 3c). In fluid inclusions of the samples from the 'GHI' bodies, the data are tightly constrained between $0^{\circ} \mathrm{C}$ to $-6^{\circ} \mathrm{C}$, with a well-defined maximum at $-4^{\circ} \mathrm{C}$ (Fig. 3b). The data obtained for the inclusions from the ' $\mathrm{N}$ ' body are comprised between $-4^{\circ} \mathrm{C}$ and $6^{\circ} \mathrm{C}$, with a peak in $-5^{\circ} \mathrm{C}$ (Fig. 3a)

The determination of the eutectic temperature (Te) was very difficult, considering that, during the re-heating after cooling, the formed phases can melt at temperatures well below the expected eutectic temperatures (metastable melting). Bodnar (1998) and Burrus

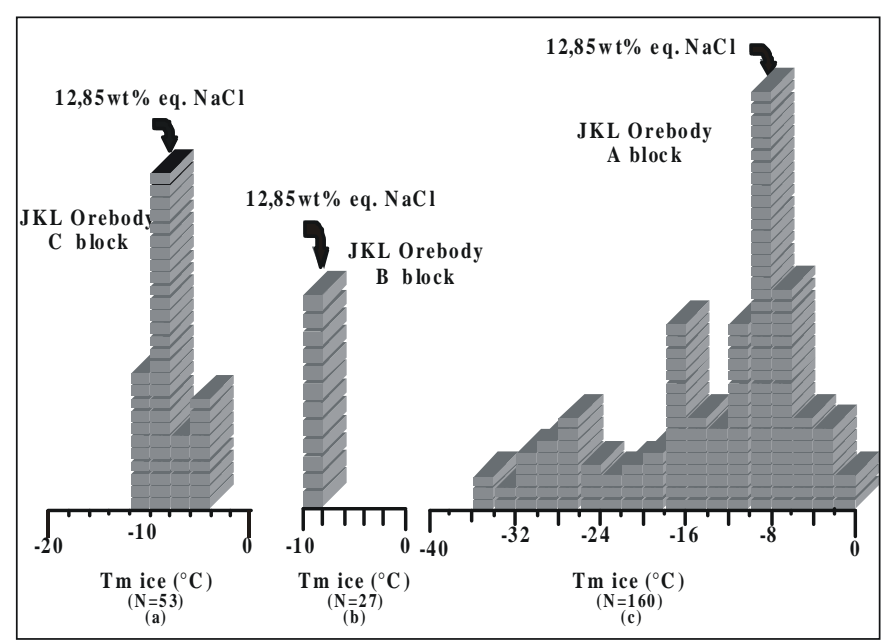

Figure 2-Histogram of ice melting temperatures for primary and pseudosecondary fluid inclusions in sphalerite from the ' $J K L$ ' orebodies ('A', ' $B$ ' and 'C' blocks). Source: Cunha 1999.

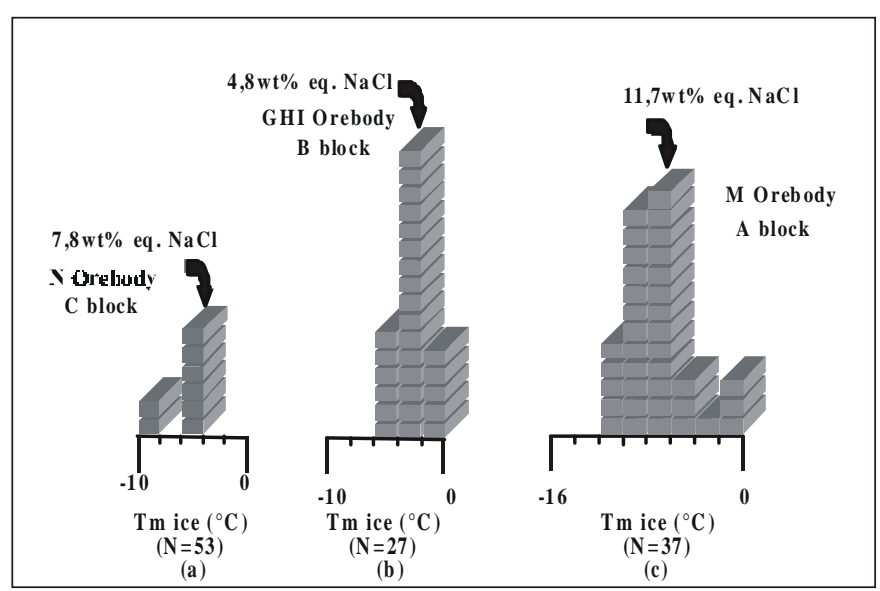

Figure 3-Histogram of ice melting temperatures for primary and pseudosecondary fluid inclusions in sphalerites from: (a) ' $N$ ' orebody- 'A' block; (b) 'GHI' orebodies - 'B' block; and (c) ' $M$ ' orebody - 'C' block (Source: Cunha 1999). 
$(1997,1998)$ alerted that some low 'eutectic' melting temperatures are more likely some type of devitrification of saline aqueous glass or solid state transition but not a melting event. Another factor that complicates the determination of the eutectic temperatures is the small dimension of the inclusions (less than $20 \mathrm{~mm}$ in average).

Based on the above-mentioned arguments, the system $\mathrm{NaCl}-\mathrm{H}_{2} \mathrm{O}$ was used as a composition model and all temperatures below $-21.2^{2} \mathrm{C}$ (notably those of the 'JKL' orebody in the 'A' block) were discarded. However, during heating from very low temperatures it has been very difficult to distinguish which crystal was melting ice or hydrohalite, due to the reduced size of the inclusions. Accordingly, the salinity was calculated separately, using the melting temperatures of ice and hydrohalite.

The melting temperatures of ice for primary fluid inclusions of the ' $J K L$ ' orebodies in the ' $A$ ' and ' $C$ ' blocks showed a well-defined maximum at $-10^{\circ} \mathrm{C}$ (Figs. 2a and 2c), which yielded a salinity of $13.94 \mathrm{wt} \%$ eq. $\mathrm{NaCl}$ and the average salinity is $12.85 \mathrm{wt} \%$ eq. $\mathrm{NaCl}$, considering the ice as the last crystal to melt (Bodnar and Vityk 1994). However, in the case of being hydrohalite the last crystal to melt, the calculated salinity is $24.81 \mathrm{wt} \%$ eq. $\mathrm{NaCl}$ (Goldstein and Reynolds 1994).

The average salinity for the ' $\mathrm{M}$ ' orebody is $11.7 \mathrm{wt} \%$ eq. $\mathrm{NaCl}$, while for the ' $\mathrm{N}$ ' and 'GHI' orebodies the well-defined maximum of the salinity is 7.8 and $4.9 \mathrm{wt} \%$ eq. $\mathrm{NaCl}$, respectively, considering the ice as the last crystal to melt (Bodnar and Vityk 1994). In the case that hydrohalite is the last crystal to melt, the salinities for the inclusions of the ' $\mathrm{M}$ ', 'N' and 'GHI' orebodies are of $25.10 \%, 25.54 \%$ and $25.84 \mathrm{wt}$ $\%$ eq. $\mathrm{NaCl}$ respectively (Goldstein and Reynolds 1994).

Minimum trapping temperatures (TH) always occurred in the liquid state, in all the orebodies. Inclusions of the 'JKL' orebodies were the only ones analyzed in the three blocks of the mine, due to their large size and abundance. The histogram of TH for fluid inclusions in the samples from the ' $\mathrm{A}$ ' block is characterized by a scattering of values from $100^{\circ} \mathrm{C}$ to $300^{\circ} \mathrm{C}$, with well-defined maximum at $165^{\circ} \mathrm{C}$ (Fig. $4 \mathrm{c}$ ). In the ' $\mathrm{B}$ ' block $\mathrm{TH}$ values are distributed between $140^{\circ} \mathrm{C}$ and $160^{\circ} \mathrm{C}$ with well-defined maximum at $155^{\circ} \mathrm{C}$ (Fig. 4b) and scattered from $80^{\circ} \mathrm{C}$ to $170^{\circ} \mathrm{C}$, with well-defined maximum at $155^{\circ} \mathrm{C}$ in the ' $\mathrm{C}$ ' block (Fig. 4a). These values indicate a decrease in TH values in the blocks away from the fault zone.

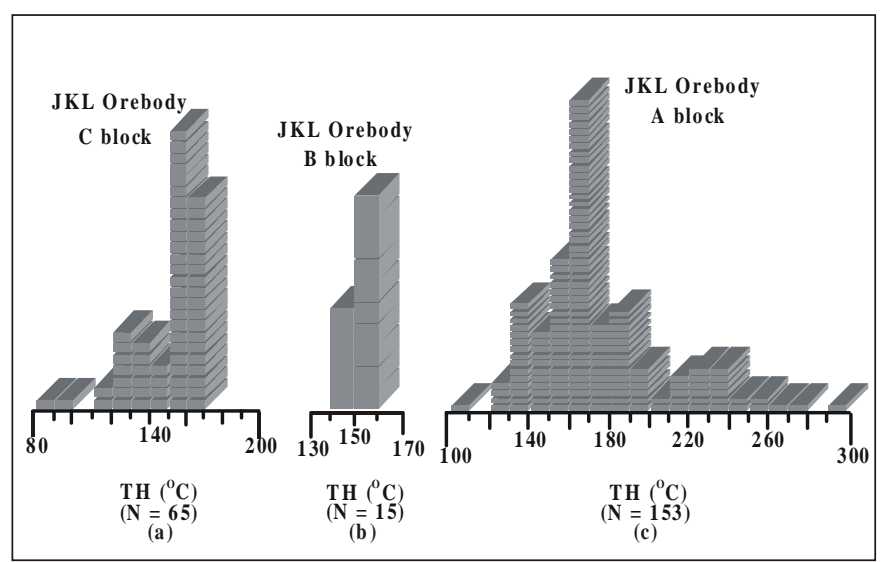

Figure 4-Histogram of total homogenization temperatures for primary and pseudosecondary fluid inclusions in sphalerites from the ' $J K L$ ' orebodies, in 'A', 'B' and 'C' blocks. Source: Cunha 1999.

$\mathrm{TH}$ values obtained in fluid inclusions of sphalerite from samples of the ' $\mathrm{M}$ ' body vary between $100^{\circ} \mathrm{C}$ and $160^{\circ} \mathrm{C}$, with a well-defined maximum at $135^{\circ} \mathrm{C}$ (Fig. 5c). Primary and pseudosecondary fluid inclusions in sphalerite from samples of the 'GHI' orebodies yielded TH temperatures that scatter between $80^{\circ} \mathrm{C}$ and $210^{\circ} \mathrm{C}$, with maximum at $165^{\circ} \mathrm{C}$ (Fig. 5b). The data obtained for primary inclusions in the stratiform ' $\mathrm{N}$ ' orebody, next to the surface, vary between $120^{\circ} \mathrm{C}$ and $150^{\circ} \mathrm{C}$, with a peak at $135^{\circ} \mathrm{C}$ (Fig. 5a).

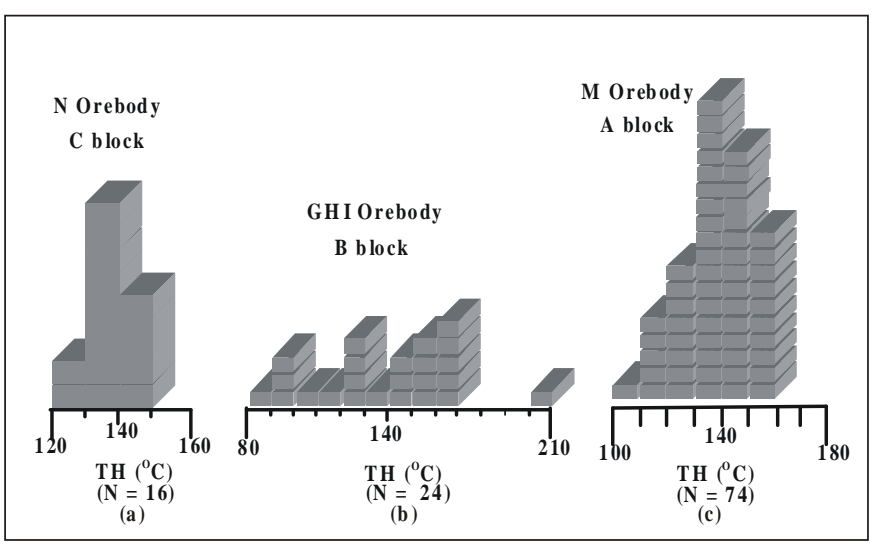

Figure 5-Histogram of total homogenization temperatures (TH) for fluid inclusions in sphalerite from: (a) the ' $N$ ' orebody, 'A' block; (b) 'GHI' orebodies, 'B' block; and, (c) the 'M' orebody 'C' block. Source: Cunha 1999.

Discussion The study of primary and pseudosecondary fluid inclusions in sphalerite from the Morro Agudo mine indicates that the mineralizing fluid was characterized by a moderate-low salinity.

The minimum trapping temperatures obtained for the primary fluid inclusions indicate a lateral thermal zoning in relation to the fault zone and a vertical zoning in relation to the surface. This thermal zoning is in agreement with those obtained previously by isotopic study using cogenetic pairs of sphalerite and galena (Misi et al. 1996).

The lateral zoning is more clear in the 'JKL' orebodies because of the possibility of comparing the salinities between the nearest block (the ' $\mathrm{A}$ ' block) and the most distant block (the ' $\mathrm{C}$ ' block) in relation to the fault zone. The more saline fluids closer to the main discharge site have possibly mixed with low to moderate saline basinal fluids that was probably responsible for the decreasing of the salinity away from the fault zone. The results suggest that the fault bordering the eastern part of the mine could have acted as a feeding zone of mineralizing fluids.

CONCLUSIONS Some results of this work allowed a better knowledge of the conditions of formation of the Morro Agudo deposit, including a better understanding of the mineralization processes. The main conclusive aspects are the following:

1) Field and petrographic studies indicated a very close relationship of the main mineralization with marine sedimentary facies, formed in very shallow, in part subaerial environment, (evaporite facies). Petrographical studies demonstrated also the presence of structures suggesting a syndiagenetic nature of at least a representative part of the mineralization. Several textures still indicate processes of carbonate substitution by sulphides;

2) the association of the orebodies with fault zones indicates a structural control;

3) the minimum trapping temperature data and salinities obtained in this study indicate a lateral thermal and salinity gradient from the main fault that limits the deposit to the east side. This could be an indication that the zone of the main fault would have worked as the main channelway for the mineralizing fluid. This fault probably corresponds to an old structure of the basement that was reactivated during and after the sedimentation. Metal-bearing brines would have migrated through this fault.

Acknowledgements The authors are grateful to the Companhia Mineira de Metais (CMM) for allowing access to the mine area, boreholes and mine maps. We thank Flávio Tolentino, Glacir Romagna and Celso Viviani, of the CMM staff for orientation in the fieldwork, support and referring information about the geology of the area. The first author is particularly indebted to the Conselho Nacional de Desenvolvimento Científico e Tecnológico (CNPq) for the financial support. This paper is a contribution to the IGCP-450 Base Metal Deposits of Western Gondwana. 


\section{References}

Bodnar R.J. 1998. Additional discussion of apparent low temperature observations that was held in february 1998. http://www.geology.wisc.edu/ pbrown/fi/disc/ loweutec2.htm

Bodnar R.J. \& Vityk M.O. 1994. Interpretation of microthermometric data for H2O-NaCl fluid inclusions. In: B. De Vivo \& M.L. Frezzotti (eds), Fluid Inclusions in Minerals Methods and applications, Short Course of the working Group IMA "Inclusions in Minerals", 117-130

Burrus R.C., 1997. short discussion of apparent low eutectic temperature observations that was held during June 1997. http.//www.geology.wisc.edu/ pbrown/fi/disc/ loweutec.html

Burrus. R.C. 1998. Additional discussion of apparent low temperature observations that was held in february 1998 http://www geology wisc.edu/ pbrown/fi/disc/ loweutec $2 \mathrm{html}$

Cunha I.A. 1999. Estudos de Inclusões Fluidas e de isótopos de enxôfre dos corpos de minérios de Zn-Pb de Morro Agudo, Minas Gerais.Universidade Federal da Bahia, M.Sc. Thesis, $126 \mathrm{p}$.

Dardenne M. A. 1978a. Zonação tectônica na borda Ocidental do Craton do São Francisco. In: SBG, Cong. Bras.Geol., 30, Recife, Anais, 1:299.

Dardenne M. A. 1978b. Síntese sobre a estratigrafia do Grupo Bambuí no Brasil Central. In SBG, Cong. Bras. Geol., 30, Recife, Anais, 2: $97-610$

Dardenne M. A. 1979. Les minéralisations plomb-zinc du Groupe Bambui et leur contexte géologique. Paris, Univ. Pierre et Marie Curie (Paris VI), Thèse de Doct. Etat. 275

Dardenne M. A., Freitas-Silva F.H., Souza J.C.F., Campos J.E.G. 1998. Evolução TectonoSedimentar do Grupo Vazante no Contexto da Faixa de Dobramentos Brasília. In: SBG, Cong. Bras. Geol., 40, Belo Horizonte, Anais, 26.

Goldstein R. H. \& Reynolds T. J. 1994. Systematics of Fluid Inclusions in Diagenetic Minerals. SEPM short course 31. 199p.
Madalosso A. 1980a. Considerações sobre a Paleografia do Grupo Bambuí na Região de Paracatú, MG. In: SBG, Cong. Bras. Geol., 31, Camburiú, Anais, 2: 772-785.

Madalosso A. \& Valle C.R.O. 1978. Considerações sobre a estratigrafia e sedimentologia do Grupo Bambuí na Região de Paracatú, Morro Agudo - MG. In: SBG, Cong. Bras. Geol., 30, Recife, Anais, 2:622 - 631.

Misi A., Iyer S.S., Tassinari C.C.G. 1996. Boquira (2.5 Ga) and Morro Agudo (0,65 Ga) Lead-Zinc Deposits, Brazil: New SEDEX Subtypes? In: Cong. Bras.Geol., 39, IGCP Project 342: Age and Isotopes of South American Ores, Resumos extendidos, 7:251 -253 .

Misi A., Iyer S.S.S., Tassinari C.G.G., Coelho C.E.S., Kyle J.R., Franca-Rocha W.J.S Gomes A.S.R., Cunha I.A., Carvalho I.G., Conceição Filho V.M. 1999 Integrated Studies and Metallogenic Evolution of the Proterozoic Sediment-Hosted Pb-Zn-Ag Sulfide Deposits of the São Francisco Craton, Brazil. In: M.G. Silva \& A. Misi

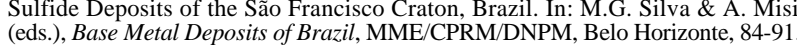
Roedder E. 1984. Fluid inclusions. In: P.H. Ribbe (ed), Reviews in Mineralogy, v. 12, Mineralogical Society of America, $646 \mathrm{p}$.

Romagna G. \& Costa R.R. 1988. Jazida de zinco e chumbo de Morro Agudo, Paracatu, Minas Gerais. In: C. Schobbenhaus and C.E.S. Coelho (Eds), Principais Depósitos Minerais do Brasil, Departamento Nacional da Produção Mineral / Companhia Vale do Rio Doce (DNPM / CRVD), v.3,111-121.

Contribution IGC-042 Received January 28, 2000 Accepted for publication April 30, 2000 